\title{
Phenol-formaldehyde resin composites filled with modified phlogopite reinforced with hybrid glass and basalt fiber meshes used as grinding wheels (Rapid communication)
}

\author{
Mariusz Oleksy ${ }^{1), *)}$, Rafał Oliwa ${ }^{1)}$, Katarzyna Bulanda' ${ }^{1)}$, Robert Szałajko ${ }^{2)}$, Grzegorz Budzik ${ }^{3)}$, \\ Izabela Skrzypczak ${ }^{4)}$
}

DOI: dx.doi.org/10.14314/polimery.2020.11.12

\begin{abstract}
The research on obtaining composites based on phenol-formaldehyde resin (PFR) with modified phlogopite quaternary ammonium salt (QAS) reinforced with hybrid glass and basalt fiber was carried out. The influence of the reinforcement structure (glass mesh weave) and the type of fiber on the performance properties of the obtained composites were assessed, especially in terms of their use a grinding wheels reinforced with modified hybrid glass and basalt fiber meshes. Based on the obtained research results, it was found that composites reinforced with a glass fiber layer mesh with a matrix of phenol-formaldehyde resin filled with modified phlogopite are characterized by higher mechanical strength, abrasion resistance and dynamic strength of the disk compared to unmodified composites.
\end{abstract}

Keywords: phenol-formaldehyde resin, QAS modified phlogopite, grinding wheels, glass fiber, basalt fiber, mechanical properties, hybrid glass-basalt mesh.

\section{Kompozyty żywicy fenolowo-formaldehydowej napełnionej zmodyfikowanym flogopitem wzmacniane hybrydowymi siatkami z włókna szklanego i bazaltowego stosowane jako ściernice}

\begin{abstract}
Streszczenie: Przeprowadzono badania nad otrzymaniem kompozytów na osnowie żywicy fenolowo-formaldehydowej (PFR) z flogopitem zmodyfikowanym czwartorzędową solą amoniową (QAS) wzmacnianych hybrydowymi siatkami z włókna szklanego i bazaltowego. Oceniono wpływ struktury wzmocnienia (splotu siatki szklanej) oraz rodzaju włókna na właściwości użytkowe otrzymanych kompozytów, zwłaszcza w kontekście ich zastosowania w charakterze ściernic. Na podstawie uzyskanych wyników badań stwierdzono, że kompozyty wzmocnione siatką warstwową z włókna szklanego z osnową żywicy fenolowo-formaldehydowej napełnionej zmodyfikowanym flogopitem charakteryzują się większą wytrzymałością mechaniczną, odpornością na ścieranie oraz wytrzymałością dynamiczną tarczy niż kompozyty niemodyfikowane.
\end{abstract}

Słowa kluczowe: żywica fenolowo-formaldehydowa, flogopit modyfikowany QAS, ściernice, włókno szklane, włókno bazaltowe, właściwości mechaniczne, hybrydowe siatki szklano-bazaltowe.

The development of grinding wheel technology contributes to the search for new construction solutions aimed at improving their performance and surface qual-

\footnotetext{
1) Rzeszow University of Technology, Department of Polymer Composites, al. Powstańców Warszawy 6, 35-959 Rzeszów, Poland.

2) Rymatex Sp. z o.o., Osiedle 42, 38-480 Rymanów, Poland.

3) Rzeszow University of Technology, Department of Mechanical Engineering, al. Powstańców Warszawy 8, 35-959 Rzeszów, Poland.

4) Rzeszow University of Technology, Department of Civil Engineering and Environmental Engineering, Poznańska 2, 35-959 Rzeszów, Poland.

*) Author for correspondence: molek@prz.edu.pl
}

ity of ground artifacts. This applies especially to grinding at high and very high speeds. Currently, improving the efficiency of grinding and the quality of grinding is obtained by modifying the construction of grinding wheels consisting mainly in the selection of the type of abrasive grains, their size, as well as the technology of applying them to the carrier so as to obtain an even distribution over the entire abrasive wheel. However, an important structural element of the abrasive wheel is also a reinforcing mesh made of glass, carbon or aramid fiber in a polymer matrix, most often phenol-formaldehyde resin (PFR). It also determines the quality of the abrasive wheel and mainly affects its life cycle [1, 2].

The purpose of this publication was to examine the mechanical strength of grinding wheels: shear stress and 
dynamic strength of the disc to centrifugal force (at the maximum rotational speed of the tested disc), additionally the surface morphology of the obtained composites was examined. The work is a continuation of research $[3,4]$ on PFR composites with the addition of modified QAS (quaternary ammonium salt) phlogopite reinforced with hybrid glass and basalt fiber meshes used as grinding wheels.

\section{EXPERIMENTAL PART}

\section{Materials}

The following raw materials were used in the experiments:

- Phlogopite modified according to the procedure described in patent [5] dimethyldecyl-2-hydroxypropyl ammonium chloride (FQAS);

- Phenol-formaldehyde resin DS.-05, Lerg Pustków, (PFR);

- Fiberglass mesh with a weave $265 \mathrm{~g} / \mathrm{m}^{2}$, manufactured by Rymatex Sp. z o.o. (S1);

- Glass and basalt fiber meshes every second warp weave, $265 \mathrm{~g} / \mathrm{m}^{2}$, produced by Rymatex Sp. z o.o. (S2);

- Basalt fiber mesh as a warp and weft of fiberglass with a gauze weave, with the same number of warp threads and a weft of $265 \mathrm{~g} / \mathrm{m}^{2}$, produced by Rymatex Sp. z o.o. (S3);

- Fiberglass layers layered and sewn with polyester thread, $265 \mathrm{~g} / \mathrm{m}^{2}$ basis weight, manufactured by Rymatex Sp. z o.o. (S4).

\section{Preparation of a phenol-formaldehyde resin} composition with the addition of modified phlogopite

The resulting QAS modified phlogopite was introduced in the range of 1.0-3.0 wt \% into the liquid phenol-formaldehyde resin using a multi-stage homogenization consisting of: pre-mixing with a slow-rotating mechanical stirrer at room temperature, after which the mixture was heated to $50^{\circ} \mathrm{C}$ and stirred in an ultrasonic homogenizer. The next stage of homogenization was carried out under reduced pressure, at a temperature of $50^{\circ} \mathrm{C}$ in a high shear mixer with a turbine stirrer rotating at the speed of $4500 \mathrm{rpm}$. Final homogenization was performed in a cylinder-cylinder type triturator, with a small gap of $\sim 0.5 \mathrm{~mm}$, to enable high shear as a result of high speed rotation of the moving cylinder, at $5500 \mathrm{rpm}$.

\section{Receiving composites reinforced with hybrid glass fibers griped with PFR composition}

The resulting composition of phenol-formaldehyde resin with 1 or $3 \%$ by mass of the addition of modified QAS phlogopite (FQAS) was used to impregnate hybrid glass and basalt fiber meshes with a gauze weave and a basis weight of $265 \mathrm{~g} / \mathrm{m}^{2}$ (S1-S3) by means of coating line [1] at $5 \mathrm{~m} / \mathrm{min}$ saturation rate and drying duct length $12 \mathrm{~m}$ at drying temperature $140^{\circ} \mathrm{C}$. For comparison, glass fiber layered mesh sewn with polyester thread (S4) also having the same basis weight. $229 \times 23\left(\mathrm{~mm}^{2}\right)$ diameter discs were cut from the nets thus obtained, from which discs were tested for disc wear test as well as rectangular samples with dimensions of $53 \times 73\left(\mathrm{~mm}^{2}\right)$ and a thread angle of $45^{\circ}$ [2] in accordance with the recommendations of ASTM Standard D 7078 and described in the publication [6], which were crosslinked at $160^{\circ} \mathrm{C}$ during 4 hours.

\section{Obtaining grinding wheels for tested composites reinforced with hybrid fabrics of glass and basalt fiber supplied with PFR composition}

Grinding wheels using tested composites reinforced with glass and basalt fiber meshes impregnated with the composition of the PFR for testing the dynamic strength of a disk to centrifugal force by increasing the rotational speed of the tested disc until the grinding wheel breaks, were made using a technological line and according to the recipe used at Techniflex. a)

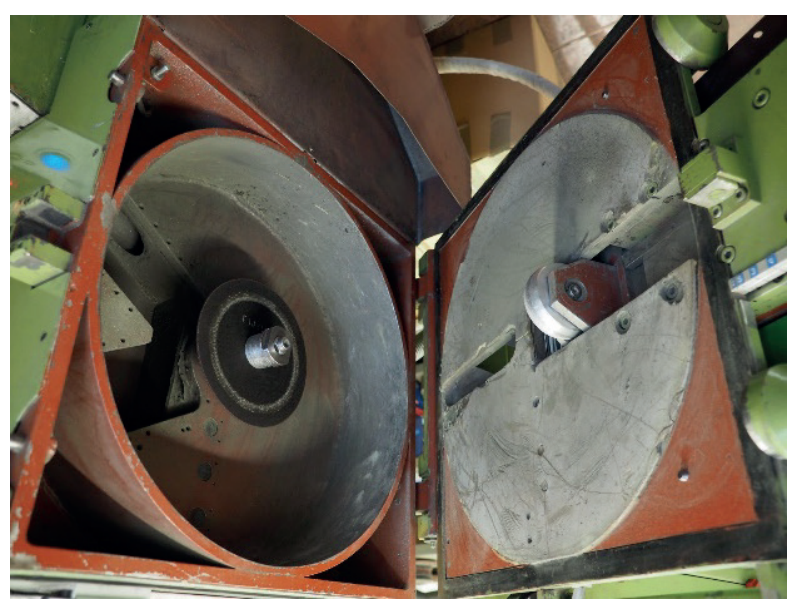

b)

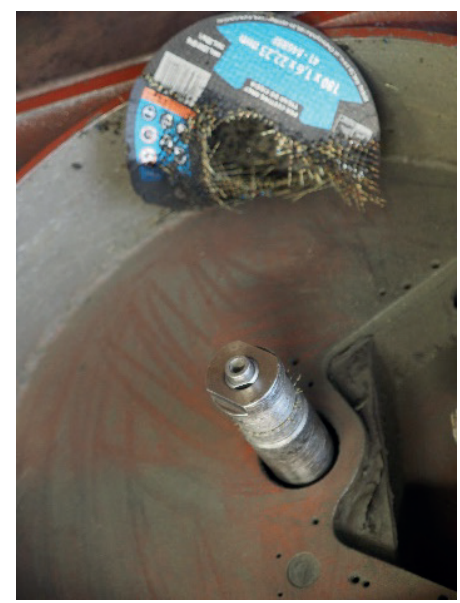

Fig. 1. a) Maternini PVM 030 device for performing grinding wheel breakage test, b) grinding wheel view after testing 


\section{Methods of testing}

\section{Mechanical properties}

- Shear strength was determined using the Shear Frame Test [1] with a stretching speed of $2 \mathrm{~mm} / \mathrm{min}$ on a Zwick/Roell testing machine for crosslinked squares with a side of $250 \mathrm{~mm}$. Shear stress was determined according Eq. (1):

$$
\tau=\frac{P}{\sqrt{2 a b}}
$$

where: $\tau$ - shear stress [MPa], $P$ - maximum force $[\mathrm{N}]$, $a$ - sample thickness [mm], $b$ - sample side length [mm].

- Measurement of the dynamic strength of a disk to centrifugal force by increasing the rotational speed of the tested disc until the wheel breaks (Fig. 1) performed in accordance with PN-EN 12413:2007. Tests were carried out for grinding wheels with a diameter of $230 \mathrm{~mm}$ and a thickness of $2 \mathrm{~mm}$, at a temperature of $25^{\circ} \mathrm{C}$.

\section{Research of morphology of surfaces suffered by composition of PFR hybrid meshes by the optical microscope}

The surface morphology of the cured hybrid glass grids was analyzed using a Vision ENGINEERING SX 45 optical microscope. A magnification of $3 \times$ was used. The NIAX Elements computer program was used to analyze the received images.

\section{RESULTS AND DISCUSSION}

\section{Assessment of mechanical properties of tests suffered with PFR compositions of glass fiber}

To determine the impact of the content of the modified QAS phlogopite on the mechanical properties of the composites tested on the PFR matrix reinforced with hybrid glass and basalt fiber meshes, the determination of shear stress and dynamic disc strength on the centrifugal force was performed by increasing the rotational speed of the tested disc until the grinding wheel breaks. The obtained results of mechanical tests are presented in Table 1.

As it results from the data presented in Table 1, a clear impact of the use of modified QAS phlogopite (FQAS) and the structural building of meshes was observed to improve the tested strength characteristics. It was also observed that the concentration of the filler in the resin had an effect on improving these properties and their optimal content in the composite was $2.5 \mathrm{wt} \%$ (Table 1). The best results were obtained for laminated glass grids with polyester (hybrid) thread and basis weight $265 \mathrm{~g} / \mathrm{m}^{2}$ (S4) impregnated with phenol-formaldehyde resin with $2.5 \mathrm{wt} \%$ FQAS (PFR+2.5\%FQAS), where a clear improvement of the tested features was achieved: dynamic strength by approx. $20 \%$, and shear stress by approx. $72 \%$ compared to matrix composites of unmodified phenol-formaldehyde resin (Table 1).

For the remaining tested composites based on phenol-formaldehyde resin with $2.5 \mathrm{wt} \%$ addition of QAS modified phlogopite (PFR+2.5\%FQAS) reinforced with S1-S3

$\mathrm{T}$ a b l e 1. Results of determinations of mechanical properties of tested composites

\begin{tabular}{|c|c|c|c|c|c|c|}
\hline \multirow{2}{*}{ Examined property } & \multicolumn{6}{|c|}{ Symbol of composite } \\
\hline & PFR & PFR+1\%FQAS & PFR+1.5\%FQAS & $\mathrm{PFR}+2 \% \mathrm{FQAS}$ & PFR+2.5\%FQAS & PFR+3\%FQAS \\
\hline \multicolumn{7}{|c|}{ Fiberglass mesh with a gauze weave, $265 \mathrm{~g} / \mathrm{m}^{2}(\mathrm{~S} 1)$} \\
\hline Shear stress, $\mathrm{MPa}$ & $0.53 \pm 0.03$ & $0.55 \pm 0.05$ & $0.61 \pm 0.03$ & $0.74 \pm 0.02$ & $0.86 \pm 0.03$ & $0.82 \pm 0.02$ \\
\hline $\begin{array}{l}\text { Dynamic breaking } \\
\text { strength of the abrasive } \\
\text { disk, rpm }\end{array}$ & $10435 \pm 26$ & $10654 \pm 21$ & $10932 \pm 19$ & $11286 \pm 23$ & $11998 \pm 22$ & $11857 \pm 20$ \\
\hline \multicolumn{7}{|c|}{ Mesh of glass and basalt fiber (every second warp) with a gauze weave, $265 \mathrm{~g} / \mathrm{m}^{2}$ (S2) } \\
\hline Shear stress, $\mathrm{MPa}$ & $0.50 \pm 0.03$ & $0.52 \pm 0.01$ & $0.59 \pm 0.02$ & $0.73 \pm 0.03$ & $0.84 \pm 0.05$ & $0.83 \pm 0.04$ \\
\hline $\begin{array}{l}\text { Dynamic breaking } \\
\text { strength of the abrasive } \\
\text { disk, rpm }\end{array}$ & $10364 \pm 18$ & $10503 \pm 23$ & $10873 \pm 19$ & $11114 \pm 18$ & $11993 \pm 22$ & $11826 \pm 21$ \\
\hline \multicolumn{7}{|c|}{ Basalt fiber mesh as a warp and weft fiberglass with a gauze weave $265 \mathrm{~g} / \mathrm{m}^{2}(\mathrm{~S} 3)$} \\
\hline Shear stress, MPa & $0.47 \pm 0.02$ & $0.49 \pm 0.02$ & $0.56 \pm 0.08$ & $0.69 \pm 0.04$ & $0.75 \pm 0.04$ & $0.74 \pm 0.05$ \\
\hline $\begin{array}{l}\text { Dynamic breaking } \\
\text { strength of the abrasive } \\
\text { disk, rpm }\end{array}$ & $9986 \pm 22$ & $10106 \pm 23$ & $10457 \pm 25$ & $10852 \pm 18$ & $11124 \pm 25$ & $11102 \pm 23$ \\
\hline \multicolumn{7}{|c|}{ Fiberglass mesh layered and sewn with polyester thread $265 \mathrm{~g} / \mathrm{m}^{2}(\mathrm{~S} 4)$} \\
\hline Shear stress, $\mathrm{MPa}$ & $0.65 \pm 0.06$ & $0.73 \pm 0.07$ & $0.87 \pm 0.06$ & $0.99 \pm 0.09$ & $1.18 \pm 0.08$ & $1.80 \pm 0.10$ \\
\hline $\begin{array}{l}\text { Dynamic breaking } \\
\text { strength of the abrasive } \\
\text { disk, rpm }\end{array}$ & $10895 \pm 17$ & $11544 \pm 22$ & $12359 \pm 21$ & $12847 \pm 15$ & $13074 \pm 16$ & $13009 \pm 18$ \\
\hline
\end{tabular}


a)

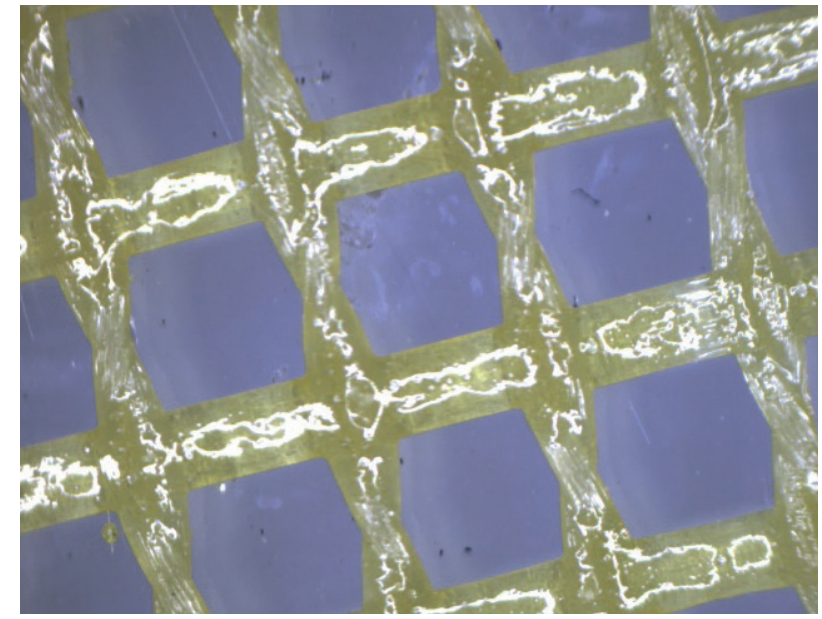

a)

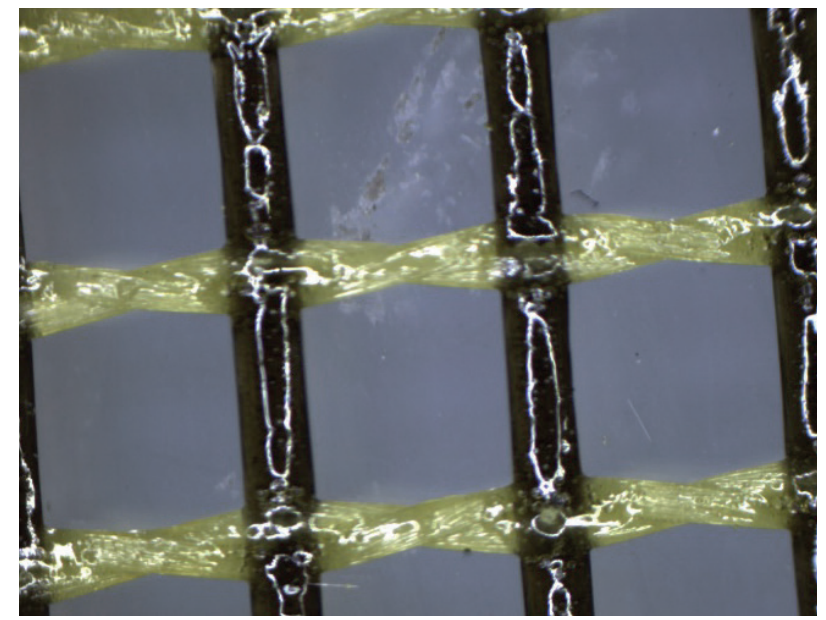

b)

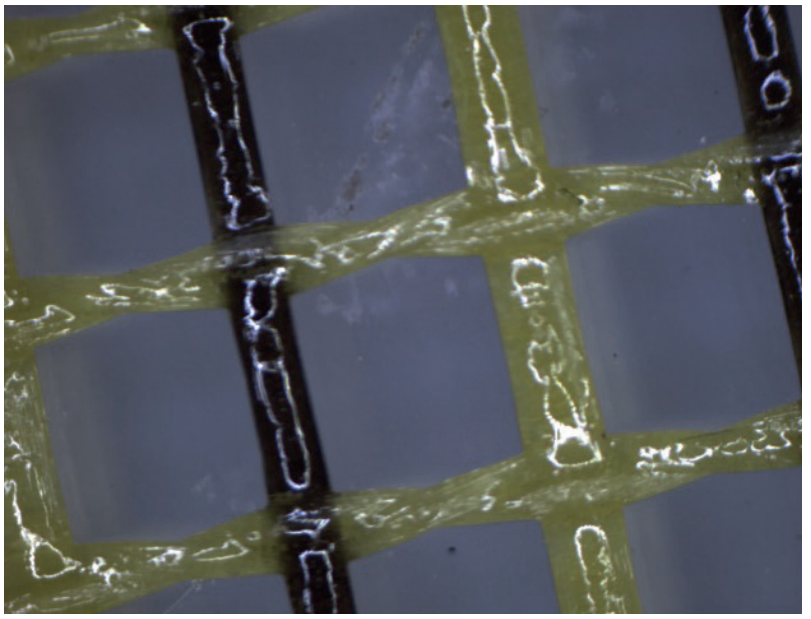

b)

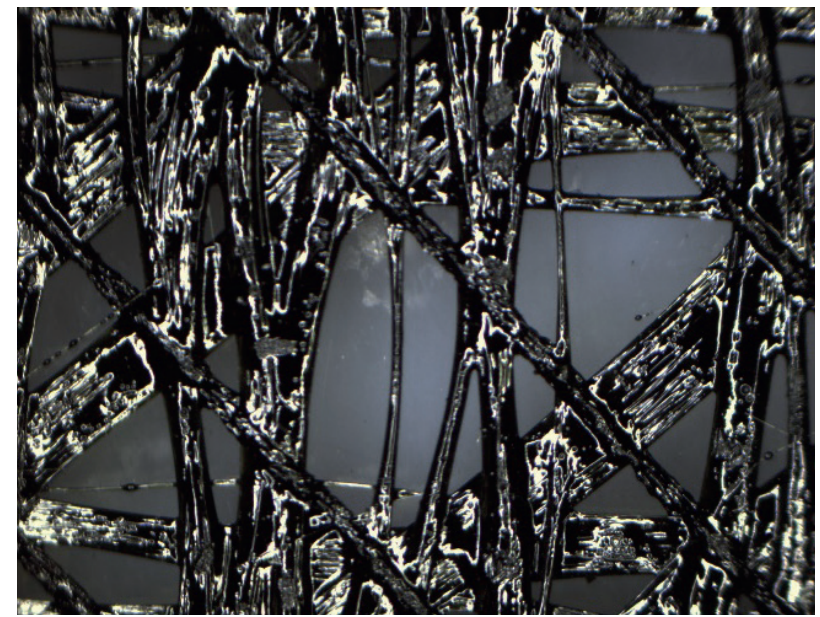

Fig. 2. View of the surface morphology of the tested meshes saturated with 2.5\% FQAS: a) S1, b) S2, c) S3, d) S4

meshes, there was an increase in dynamic strength $(R D)$ and shear stress $(\tau)$ for the reinforced composite: $S 1-R D$ by $15 \%$ and $\tau$ by $65 \%, S 2-R D$ by $16 \%$ and $\tau$ by $68 \%$ and S3 $-R D$ by $12 \%$ and $\tau$ by $59 \%$ (Table 1 ). Increasing the FQAS content in the tested composites did not improve the tested parameters, it even worsened them.

\section{Analysis of surface morphology suffered with PFR composition of hybrid meshes by the optical microscope}

The study was performed for meshes impregnated with compositions on the PFR matrix with $2.5 \mathrm{wt} \%$ addition of FQAS in a direction parallel to the arrangement of the fibers. The aim of this study was to assess the effect of FQAS on the supersaturation of the meshes tested.

The surface morphology of the tested grids impregnated with the composition of PFR+2.5\%FQAS in all cases indicates full supersaturation of the grids (Fig. 2). We observe a few air bubbles that can be associated with the so-called thixotropy effect, which is often given as a result of the addition of modified layered aluminosilicates which is phlogopite. The largest clusters of bubbles were observed at the place of stitching with polyester thread for S4 hybrid layer meshes (Fig. 2d).

\section{SUMMARY}

- As a result of the optimized homogenization method, the QAS modified phlogopite was easily dispersed in the matrix of phenol-formaldehyde resin (PFR) used for supersaturation of the examined hybrid meshes.

- The addition of modified QAS phlogopite slightly increased the viscosity of the composition on the PFR matrix, which probably affected the number of air bubbles observed by means of a microscope.

- On the basis of the obtained test results, it was found that the PFR+2.5\%FQAS matrix composite had the best performance properties.

- Increasing the FQAS content in the tested composites does not improve the tested functional properties of the composites. 
This project is financed by the Minister of Science and Higher Education of the Republic of Poland within the "Regional Initiative of Excellence" program for years 2019-2022. Project number 027/RID/2018/19, amount granted 11999900 PLN.

\section{REFERENCES}

[1] Yang L., Fu Y., Xu J., Liu Y.: Materials \& Design 2015, $88,827$. https://doi.org/10.1016/j.matdes.2015.09.066

[2] Yang L., Chu J., Fu Y. et al.: International Journal of Precision Engineering and Manufacturing 2015, 16 (12), 2599. https://doi.org/10.1007/s12541-015-0332-6

[3] Szałajko R., Oleksy M., Oliwa R., Budzik G.: Polimery 2016, 61, 855.

http://dx.doi.org/10.14314/polimery.2016.855

[4] Oleksy M., Oliwa R., Szalajko R. et al.: Polimery 2018, 63,81 .

http://dx.doi.org/10.14314/polimery.2018.2.1

[5] EP Pat. 14461559.8 (2015).

[6] Gashti M.P., Allahyary H., Nasraei P., Gashti M.P.: Fibers and Polymers 2013, 14, 1870.

http://dx.doi.org/10.1007/s12221-013-1870-0

Received 15 V 2020. 